\title{
Black theology versus black spirituality and black faith: The centrality of spirituality and faith in black theology of liberation in the South African context
}

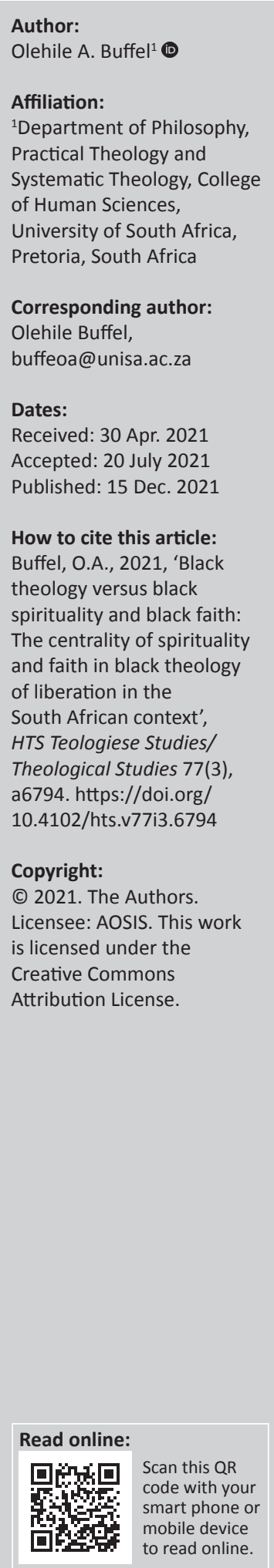

Black theology, which is linked to black power in the context of the United States of America and black consciousness in the context of South Africa is often regarded as having nothing to do with spirituality, faith and salvation. It is often regarded by critics as radical, militant and political. In some circles its theological character is questioned. Advocates of liberation theology, past and present are accused of mixing religion with politics. The article traces the history of black theology, as part of liberation theology, which started in the 1960s in three contexts, namely Latin America, United States of America and South Africa. The article argues that spirituality, faith and salvation are central to black theology of liberation. The critical theological reflection that black theology of liberation is all about happens in the context of the spiritual journey of the poor believer and oppressed.

Contribution: The contribution that this article makes is to serve as a corrective discourse that rebuts the mistaken accusation that black liberation theology has nothing to do with spirituality and faith. The article makes a direct link between spirituality and faith on the one hand and on the other hand liberating Christian praxis of the poor in their spiritual journey, in the context of South Africans as they struggle to liberate themselves amid poverty, service delivery struggles and COVID-19 and its implications.

Keywords: black theology; liberation theology; spirituality; faith; the poor; context.

\section{Introduction}

On the face of it, black theology is often dismissed as political ideology. Its theological nature is often questioned. In some circles, liberation theology has been 'dismissed as no more than the latest fad' (Brown 1978:110). It is also often dismissed as merely another form of political protest (Maimela 1990:171). Black theology of liberation is often dismissed as not theological and as having nothing to do with faith, spirituality or salvation. Critics include inter alia the following: adherents of Afrikaner Christian Nationalism, Afrikaner Reformed Churches, Conservative Evangelical Churches, white Pentecostal churches and some English-speaking churches. These are the churches and theologians who according to Vila-Vicencio $(1988: 15,25)$ 'have for various historical reasons come to symbolise the legitimation of the white status quo and white domination'. One of the fiercest opponents of black theology was Prof. C. Boshoff, who was also a former chairperson of the Afrikaner Broederbond and founder of Orania, a white people's only town in the Northern Cape. His view was that black theology of liberation is bad news and that it destroys all possibilities of communication and reconciliation between white and black people (Boshoff 1972:1). Boschoff was supported by Rev. P.E.S. Smith, who regarded black theology as nothing more than an ideology but a socio-political theology (Smith 1972:23). Concurring with this is Prof. Dionne Crafford, who regarded black theology as only atheistic in orientation (Crafford 1972:45). The three theologians had these strange and shameful views about black theology and extremely paternalistic views about black people. This is notwithstanding the fact that their writings display a thorough reading and knowledge of the initial writings on black theology in the context of the United States of America and South Africa.

In other circles, black theology is questioned as a theology and as an academic discipline. It is subjected to an unspoken question: 'Is black theology a theology at all?' (Tutu 1985:160). This is a similar question to the one posed to Reddie (2020:1) by one of his examiners during his viva voce, namely, 'Is there such a thing as black theology?' Proponents of liberation theology are often accused of wrongly mixing religion with politics. In protesting against this mistaken accusation, Tutu (1985) says:

Note: Special Collection: VukaniBantuTsohangBatho - Spirituality of Black Liberation, sub-edited by Fundiswa Kobo (University of South Africa) and Rothney Tshaka (University of South Africa). 
I have not heard the victims of oppression, those who live in the ghettoes or uprooted and dumped in resettlement camps or banned and those detained without trial, accuse us of mixing religion with politics. If anything, they are concerned that the church is often not involved enough. It is almost always those who benefit from the socio-political and economic dispensation who accuse religious people of mixing religion with politics. (pp. 162-163)

Writing primarily in the context of Latin America, Berryman (1987) states that liberation theology is erroneously portrayed as 'an exotic brew of Marxism and Christianity or as a movement of rebel priests bent on challenging church authority' (p. 4).

In defense of liberation theology, Gutierrez (1973:xiii) states that the purpose of liberation theology is not to elaborate on an ideology to justify postures already taken. Rather it lets the theological reflection be judged by the word of the Lord, to think through faith, to strengthen the love of those committed Christians and to give reason for hope from within a commitment that becomes radical, total and efficacious (Gutierrez 1973:xiii). The goal of liberation theology is to reconsider and reflect on the great themes of Christian life within this radically changed perspective and with regard to the new questions posed by Christian commitment (Gutierrez 1973:xiii). In contemporary South Africa, these themes are reconsidered in the context of pain and suffering as a result of poverty, which is currently compounded by high levels of corruption and by the COVID-19 pandemic. Aligning himself with the great themes of the Christian faith, Berryman (1987:4) points out that proponents of liberation theology write about the same topics that Christian theologians have always taken up, namely God, creation, Jesus Christ, grace and so forth. This is only performed from the perspectives and experiences of the poor and oppressed. Arguing in the context of black theology, Chikane (1985:99) states that black theologians read the Bible from the perspectives of their lived experiences and situations. They correctly read it as a book of liberation. The current context in which the poor are reading and rereading the Bible is characterised by poverty, which is exacerbated by rampant corruption and the COVID-19 pandemic. These are the realities that pastors and black theologians cannot ignore, as they journey with the poor in their struggle for liberation.

The main argument of this article is that spirituality and faith are central to Liberation theology, whether it is developed and articulated in Latin America, North America, United Kingdom, South Africa or anywhere else in Africa. That is certainly the case in the context of black theology of liberation in South Africa where there is an abundance and depth of spirituality among the poor and oppressed.

\section{The beginning of liberation theology}

The expression 'liberation theology' came into existence at Chimbote, Peru in July 1968, just several weeks before the Latin American episcopate at Medellin conference (Gutierrez 1973:xviii; cf. Berryman 1987:24; Gibellini 1987:2). A few weeks before the bishops' meeting, Gutierrez outlined a 'theology of liberation' in a talk in Chimbote, Peru (Berryman 1987:24; Gibellini 1987:2). That was the first use of the expression in Latin America (Berryman 1987:24). Soon thereafter, in 1969 Gutierrez produced a publication under the title Towards a Theology of Liberation (Hacia una teologia de la liberation). That was followed by a book with the title Theology of Liberation in December 1971, which was the first systematic discussion of liberation theology, which was translated into English in 1971 (Gibellini 1987:3).

That may be the first time that the phrase 'liberation theology' was used. However, God's people who are suffering have always reflected and grappled with the reality of suffering and the whereabouts of God amid suffering, even long before the use of the phrase 'liberation theology'. The theological reflections in the context of poverty and suffering continue throughout all the ages and contexts where there is suffering. That should continue even in the context in which poverty is exacerbated by COVID-19 and by corruption that is so widespread in the South African context.

The expressions 'liberation theology' and 'black theology' may have been new during the 1960s and 1970s but what they deal with are realities that the poor and oppressed have always grappled with. In the South African context, Motlhabi (1972:1) correctly points out that: 'black theology is not a new phenomenon. It has been with us almost since the Churches from the white west arrived on our soil'. It will continue to be with us for as long as the majority of those who are poor are black in the South African context.

According to Tutu (1979:163), liberation theology more than any other kind of theology arises out of the crucible of human suffering and anguish. It arises out of the pain and suffering that is caused by poverty and oppression. Liberation theology stems from trying to make sense of human suffering when those who suffer are the victims of organised oppression and exploitation, when they are emasculated and treated as less than they are: human persons created in the image of the triune God, redeemed by Our Saviour Jesus Christ and sanctified by the Holy Paraclete (Tutu 1979:163). This is the genesis of all liberation theology and of black theology, which is a theology of liberation in South Africa.

Boesak (1979:169) points out that liberation theology developed within a framework of a new consciousness, whether in South Africa, Latin America or other parts of the Third World (Developing World). This is a historical consciousness of suffering that Maimela (1990:175) regards as a source of liberation theology. Liberation theology arises in a context where people become aware of their own situations, their socio-economic and political dynamics (Boesak 1979:169). It is for that reason that Boesak (1979:171) refers to black theology as a situational theology, as it has always been theology in context. What underlies liberation theology is a prophetic and comradely commitment to the life, the cause and struggle of millions of debased and marginalised human beings, a commitment to 
ending historical iniquity (Boff \& Boff 1987:3). Expressing it more or less the same way, Pinn (2010:20) correctly states that Black theology is a theology that is committed to addressing the lived experience and the human need. Gibellini (1987:1) says that liberation theology has its roots in the line of prophetic theology. Maimela (1990:171) correctly points out that 'liberation theology comes from people who have become acutely aware of being oppressed and downtrodden and who are no longer prepared to put up with this'.

\section{What is liberation theology?}

Gutierrez defines liberation theology as 'a theological reflection born of shared efforts to abolish the current unjust situation and to build a different, freer and more human ... a just and fraternal society' (Gutierrez 1973:xiii, xiv). It is a reflection on the practice in the light of faith (Gutierrez 1999:27). Put slightly differently, Berryman (1987:4) defines liberation theology as a systematic, disciplined reflection on Christian faith and its implications.

This liberation theology is articulated from the perspectives and experiences of the poor, as they interpret Christian faith and as they read and re-read the Bible and key Christian doctrines with the eyes of the poor (Berryman 1987:4).

Liberation theology is pre-eminently a way of looking at life 'from below', that is, from the perspectives of the poor, the dispossessed and the marginalised (Brown 1978:52). In agreement with this, Gibellini (1987:1) refers to liberation theology as 'a theology from the underside of history'. The poor are the starting point of liberation theology. The poor and the marginalised are the people about whom the rest of society could not care less (Brown 1978:60). According to Dom Helder Camara, 'a marginal person is someone who is left by the wayside in the economic, social, political and cultural life of his (sic) country' (Camara in Brown 1978:60). Brown says that it is with the poor that theology must start, and not with theories, but with 'the view from below' where the pain is (Brown 1978:61). The poor are not only the nonpersons but also the interlocutors of liberation theology (Brown 1987:60). In this way the poor learn to read the Scripture in a way that affirms their dignity and self-worth and their right to struggle together for a more decent life (Berryman 1987:5). Gutierrez and Berryman were writing in the context of Latin America where the poor were subjected to injustices and conditions that were dehumanising. Liberation theology is not unique to Latin America but expressed in theologies in the United States of America, Asia, Africa and other contexts (cf. Berryman 1987:6). In the South African context, we still have the poor who are subjected to a plethora of systemic injustices and socioeconomic and political conditions that are dehumanising, hence that definition is still applicable to South Africa. Liberation theology, like any other theology is about God. In my view, it is not only about God but about God's people and their living conditions marked by poverty and oppression.

\section{Black theology of liberation in the South African context}

The phrase black theology is a phenomenon of the 1960s, which has its theological roots in pre-Civil War black church, which recognised that racism and Christianity were opposites (Cone 1972:29). Cone (1972:29) describes it as a religious counterpart of the more secular term 'Black Power'. In the South African context, the secular term which became associated with black theology is black consciousness (Cone 1972:28; cf. Pityana 1972:37).

Black theology is the theological reflection of black Christians on the situation in which they live and on their struggle for liberation (Boesak 1976:1). There are striking similarities between the situation of black people in the United States and that of black people in South Africa.

In concurrence with the given statement, Cone (1972:28) describes black theology as a religious explication of the need for black people to define the scope and meaning of black people in a racist society and an explication of the meaning of God's liberation of the poor and oppressed.

In contemporary South Africa, the affirmation of emancipating or liberating black humanity occurs in the context of dehumanising poverty, in the context in which sadly the political power is in the hands of black leaders since 1994. This fact makes the process and method of doing theology (black theology) in South Africa a 'very controversial' process, in more or less the same way as it was during the hey days of apartheid, as Goba (1988) asserted during the 1980s: 'Doing theology in the South African situation has become a very controversial subject because of its interest in confronting the political realities of the South African situation'. The difference is that it is now no longer the white minority apartheid regime, but black people who wield political power, who have allowed poverty to worsen and to continue to affect black people, who share the heavy burden of poverty. It means that it is now black people who preside over the suffering of their fellow blacks. It is black people who have political power and under whose leadership corruption has found a fertile ground at the expense of the poor.

Black theology according to Boesak (1976:13) is a situational theology. It is the black people's attempt to come to terms theologically with their black situation. Earlier in 1972, Steve Biko, then a young man addressing the elderly, described black theology as situational interpretation of Christianity (Biko 1978:59). Black theology is also contextual and seeks to interpret the gospel in such a way that the situation of black people will begin to make sense (Boesak 1976:13). According to Cone (1997):

[T] he task of black theology is to analyse the black man's (sic) condition in the light of God's revelation in Jesus Christ with the purpose of creating a new understanding of black dignity among black people. (p. 117) 
Cone (1997:117) states that black theology is primarily a theology of and for black people who share the common belief that racism will be destroyed only when black people say in word and deed to the white racist: 'We ain't gonna stand any more of this'. Buthelezi (1972:9) states that the black person must be enabled to realise that blackness like whiteness is a good natural face from God and not some cosmological curse.

In the current context of increasing poverty, in which the rich are becoming richer and the poor poorer, black people who are impoverished are grappling with their black situation of poverty, which is now being exacerbated by COVID-19.

\section{Who are the poor and what is poverty?}

The poor are those whom Gutierrez $(1981: 107,108)$ refers to as the common people who are from the bottom and are also anonymous. These are the poor, who belong to social groups, races, classes, cultures, gender groups and groups that are usually marginalised. These are the non-persons, that is, those who are not recognised by the existing social order, namely the exploited, and those who are systematically and legally deprived of the status as human beings (Gutierrez 1999:28). According to Vellem (2012): 'The non-person originally meant that blacks lives are doomed to second class citizenship, it meant poverty in squalid conditions and it meant ultimately being less than human'.

In the South African context, the black folk who are the majority of those who are poor may no longer be excluded by the statutes but continue to be impoverished by both the legacy of legal/statutory exclusion and the failure of the African National Conference (ANC)-led government to transform the economy.

Various words and formulas are used to describe the poor and the oppressed, inter alia, they are referred to as: the dominated peoples, the exploited classes, the despised races and the marginalised cultures (cf. Gutierrez 1973:xxi). They are not to be regarded only as individuals but part of a collective. Even in the Bible, the poor are part of a social group. They are the lowly of the land who are harassed, robbed of the fruit of their labour, exploited and oppressed by injustices (Gutierrez 1981:112). In the Latin American context, John Baptist Metz refers to the poor as 'those who are eking out the most wretched of existences' (Metz 1990:114). The poor are also referred to as 'the crucified people of God' who die long before their time (Sobrino 1990:121). They die as a result of 'institutionalised violence' (Sobrino 1990:121; cf. Gutierrez 1973:xxi). Brown (1978:12) is correct in arguing that fewer people would die if we had a more just and humane economic system.

In the South African context, the poor are black people, notwithstanding the fact that there are a few whites who are poor. The poor are those who under apartheid were classified as non-whites by the white ruling class (cf. Motlhabi 1972:1).
Many people who are poor in South Africa and many countries in the developing world, live in terrible conditions. They live in what others refer to as the human and social hell' (Boff \& Boff 1987:3).

The poor and oppressed face issues that Boesak (1976:3) says are 'too horrendous to contemplate'. In South Africa, the poor live in predominantly black townships, informal settlements and villages. Those who are employed do not have decent jobs and are underpaid. Millions of the poor are unemployed. Millions live on government grants, which are not enough to sustain them. Millions do not have decent houses and they live in informal settlements and in shacks and other dwellings that are not suitable for human beings. They have no access to decent healthcare services, no decent education and educational facilities and service delivery is either inadequate or non-existent.

The poor live in a complex world, which is a universe in which socio-economic aspect is basic but not all-inclusive (Gutierrez 1973:xxi). According to Gutierrez (1973:xxi), poverty to the poor means death: lack of food and housing, the inability to attend properly to health and educational needs, the exploitation of workers, permanent unemployment, the lack of respect for one's dignity and unjust limitations placed on personal freedom in the areas of self-expression, politics and religion. Gutierrez was writing in the context of Latin America in the late 1960s and early 1970s. It is interesting and disturbing that this description of the meaning of poverty was relevant for South Africa during that time. The description continues to be accurate for South Africa even nearly three decades after the dawn of a democratic, non-racial and nonsexist South Africa. Poverty continues to be one of the greatest challenges to Christian witness (Gutierrez 1987:20).

The poor are not poor by accident or poor as a result of their laziness, as it is often erroneously believed. As Berryman correctly states that people do not simply happen to be poor and that the status of poverty is largely a product of the way society is organised. It is for that reason that Berryman says, 'Hence, liberation theology is a critique of the economic structures that enable some Latin Americans to jet to Miami or London to shop, while most of their fellow citizens do not have safe drinking water' (Berryman 1987:5).

\section{Poverty as the scandalous reality experienced by the poor and oppressed that is not pleasing to God}

In the context of Latin America, as the poor and oppressed articulated their liberation theology, their experience was that of the reality of misery. This is a scandalous reality, which was described as follows by the bishops at the Puebla meeting of Latin American Episcopal Council (Conference of the Catholic Bishop often referred to as CELAM in 1979):

It is the most devastating and humiliating kind of scourge. And this situation finds expression in such things as a high rate of infant mortality, lack of adequate housing, health problems, 
starvation wages, unemployment and underemployment, malnutrition, job uncertainty, compulsory mass migration, etc. [Puebla 29] (in Boff \& Boff 1979:2)

This scandalous reality described this way in 1969 , is not any different from the experience of the poor and oppressed in the developing world, particularly in South Africa, where many people live in what Ernesto Cardenal refers to as 'subhuman conditions' (Cardenal in Assmann 1975:1). Poverty is inhuman and has socio-economic-cultural and political causes (cf. Gutierrez 1981:111). Poverty is not accidental or by chance but caused by and entrenched in societal structures. According to Sobrino (1990:121), poverty is generated by unjust structures. The poor person is a product or by-product of an economic and social system fashioned by a few for their own benefit (Gutierrez 1981:111). This benefit of the few is often at the expense of the poor, who are most of the time the majority. They die long before their time. They are subjected to premature and unjust death (Gutierrez 1999:19). They are victims of hunger and bullets (Gutierrez 1981:111; Sobrino 1990:121). In the South Africa context, the poor have no choice but to go to the streets to protest and they end up dying because of bullets from the police such as in the case of the 34 Marikana miners in 2012 and earlier Andries Tatane, who was brutally killed in cold blood by the police in a service delivery protest in Ficksburg in 2011. This is apart from the slow death because of hunger and illnesses amid poor health services. This is a scandalous reality faced by the poor, that is, premature death.

The Puebla Document continues to state that this scandalous reality cannot be pleasing to God! (Boff \& Boff 1979:3).

This insult to the poor and oppressed is an insult to God the creator, as Gutierrez correctly observes that: 'Our relationship with God is expressed in our relationship with the poor' (1983:8). Gutierrez goes on to cite Proverbs (17:5), which aphoristically put it this way: 'To mock the poor is to insult the creator'. (Gutierrez 1983:8). God takes serious offence at the dehumanising poverty that God's people experience.

What the poor and oppressed experience as they go through misery and oppression, is contrary to the will of the God of Christian revelation who wants us to live life in abundance (cf. Gutierrez 1973:xxii; cf. Jn 10:10b).

\section{Liberation theology and spirituality}

Contrary to belief by critics (especially right-wing critics) of liberation theology who dismiss liberation theology as only political and Marxist, 'at the core of liberation theology is spirituality' (Berryman 1987:151). Arguing in the South African context, Tutu (1985:161) points out that the spiritual is central to all that we do. Vellem (2014:5) supports the centrality of spirituality in the life of Africans, who believe that the whole life is infiltrated by spirituality. The truth of the matter is, as Leonardo Boff once pointed out in the context of Latin American Liberation Theology, 'At the roots of the theology of liberation we find a spirituality, a mysticism: the encounter with the Lord' (in Boff \& Boff 1979:2). Leonardo Boff goes on to point out that 'any theology that is not based on a spiritual experience is mere panting - it is religious breathlessness' (in Boff \& Boff 1979:2). Gutierrez (1999:27) says that spirituality is one of the fundamental concerns of liberation theology. Every human being has a spiritual life, a basic spirituality (Sobrino 1996:235, 236). Sobrino (1996:245) says that the fact that there is a practice of and struggle for liberation is itself a great testimony to spirituality. With regard to the truth about spirituality being the reality for black people, Hopkins (2002) is correct when he states that the spirituality of black people arises out of their experience of social change. It is out of their existential struggles with realities of life, including the struggle against poverty, struggles with service delivery, corruption and the COVID-19 pandemic and its local and global impact.

Throughout the history of the church, authentic, genuine theology has always been spiritual, that is, to believe (life) and to understand (reflection) are part of a circular relationship (Gutierrez 1999:29). Liberation theology is true theology and like all theology, it springs from a true meeting with God in history (Boff \& Boff 1987:3). It springs from a spirituality in the context of struggles and harsh living conditions. Liberation theology, according Maimela (1990:172), is a genuine spiritual phenomenon. It is a spiritual phenomenon driven by theological reflection in the context of poverty. Theologians must have an ongoing dialogue with the poor who are doing theology, they articulate and explicate that religious, spiritual experience and vision.

\section{Liberation theology and faith}

As the poor and oppressed are engaged in the struggles of liberation, they do so as people of faith, as theists. This is in line with what liberation theology is all about, that is faith confessed and lived out or acted upon in socio-economic and political contexts. The matter of faith confessed is taken forward by Vellem (2013:161) when he poignantly argues that: 'What this implies is that the emphasis of socio-political praxis in Black Theology of liberation is faith confessed in the struggle for life'.

The poor and those who struggle along the poor believe in God. They also believe that poverty that dehumanises human beings is an offence against God (cf. Berryman 1987:32). In the context of Africa, we know with certainty that Africans are people of faith. As Mbiti (1969:1) once pointed out, Africans (black people) are 'notoriously religious', that is, they have a set of beliefs and practices, as religion permeates all the departments of life (cf. Pityana 1972:37). The overwhelming majority of the poor who are black are also believers. A significant number of the poor are Christians. They also struggle with the relevance of their faith in the current situation of poverty and their struggles with service delivery and now with COVID-19 and its implications, which are worsening their harsh living conditions. Tutu concurs that in the context of the South African spirituality and faith, Africans have always been a deeply religious people (Tutu 1985:159). 
Inevitably the people of faith engage in theological reflections all the time, and this makes theology, that is, black theology of liberation to be 'an expression of the community of faith within a particular context' (Goba 1988). Writing in the Latin American context, Gutierrez says the poor are the people who are simultaneously oppressed and believe in God (Gutierrez 1973:112). Faith is equally particularly important in the South African context. Writing in that context, Boesak poses the question that is asked by black people in South Africa: 'What does it mean to believe in Jesus Christ when one is black and living in a world controlled by white racists?' Racism may no longer be in the statutes in South Africa, but it continues to be prevalent. From time to time, racism rears its ugly head. In a supposedly non-racial and non-sexist society we still have black people constituting the majority of those who are poor. They may ask the question raised by Boesak in a slightly different way: What does it mean to believe in Jesus Christ when one is black and poor in a country where political power is in black hands? Black people in the South African context may go on to ask: What does it mean to believe in Jesus Christ in a context in which so many years after political liberation, black people continue to live in situations characterised by poverty? This is notwithstanding the fact that they live in a country with the world's most acclaimed constitution that promises transformation, guarantees of human rights, justice, freedom and equality. It is a constitution that according to Ngcukaitobi (2018:x), stands as a monument in the world and a model for the world.

Faith is of critical importance in liberation theology and in associated Christian activism. Christian faith cannot remain neutral with regard to the struggle for liberation (cf. Boff 1979:16). The Christian faith of the poor affects in different ways their experience of poverty and oppression. This experience of poverty and oppression makes its mark on their experience of the gospel (Gutierrez 1999:21). This experience also makes its mark on their theological reflections in the context of poverty and suffering. In liberation theology, faith confronts the injustices that are directed to the poor and oppressed.

Faith, according to Gutierrez, is an act that is at the root of all theology. It is not there as a mere intellectual acceptance of the message but a warm welcome of the gift of the word heard in the community of the Church, as an encounter with the Lord (Gutierrez in Assmann 1975:14). Our encounter with the Lord does not make us live in what Tutu refers to as 'an exclusive spiritual ghetto' (Tutu 1985:161). This encounter with the Lord launches us into the world, to work together with God for the establishment of God's kingdom (Tutu 1985:161). This is the kingdom of justice, peace, righteousness, compassion, caring and sharing (Tutu 1985:161). This encounter transforms those who encounter the Lord into agents of transformation, the encounter which is not unrelated to faith and spirituality.

According to Leonard Boff, faith is not a brake or a restraint but instead a spur, a driving force in liberating Christian praxis and activism (Boff \& Boff 1979:17). As Christians grapple with the harsh realities related to economics and politics, these are not separated or isolated from theological and spiritual dimensions (cf. Boff \& Boff 1979:17). As a result Christian commitment to economics and politics, according to Leonardo Boff, 'involves a commitment to God, to the kingdom and to salvation' (Boff \& Boff 1979:17). This is also a commitment to the belief that God is involved in human history. This is a commitment to the truth that God is a loving and caring God who continues to speak in history (Assmann 1975:3). As Assmann (1975:3) correctly points out, God did not suddenly stop talking after the last book of the Bible. God continues to speak and to act amid the struggles of the poor people, that is, the common people. God does not only speak but continues to be found at work in the life and situation of the poor (cf. Brown 1978:61). It is in the context of those liberation struggles that there are theological formulations, which are underpinned by circular relationship between commitment and theological reflections (cf. Gutierrez 1981:107). According to Gutierrez, we cannot separate our discourse about God from the historical process of liberation (Gutierrez 1973:xviii). The poor and oppressed are not only involved in the struggles to liberate themselves but they also believe in God, in addition to being poor and oppressed (cf. Gutierrez 1981:112). This situation of poverty and oppression does not eliminate the people's character as believers. The poor, the crucified are themselves bearers of salvation and agents thereof in the process of salvation in its totality. They have agency in their spiritual journey and in their socioeconomic and political struggles for liberation. According to Gutierrez (1973:xiv), they are 'agents of their destiny'. The poor have begun to see themselves as subject of their own history and able to take their own destiny in their own hands (Gutierrez 1999:21).

The poor, like all people are spiritual beings, they are believers. The poor collectively protests their poverty and oppression as believers and spiritual beings. Protests are part of their journeys of faith. Gutierrez states that being poor is also a way of living, thinking, loving, praying, believing, hoping, spending leisure time and struggling for a livelihood (Gutierrez 1973:xxi).

\section{Liberation theology and salvation}

Liberation is not at all unrelated to the journey towards salvation, in all its dimensions, horizontal and vertical. Sobrino boldly declares that the poor, who are the crucified peoples of God, do offer salvation, positive salvation (Sobrino 1990:126). Salvation is not unrelated to the faith and spirituality of the poor. They have an evangelising potential and presence (Sobrino 1990:127). In historical language, the poor have a humanising potential because they offer community against individualism, cooperation against selfishness, simplicity against opulence and openness towards transcendence against blatant positivism (Sobrino 1990:127). Sobrino (1990) traces the roots of this truth from the suffering servant of Yahweh, in his article titled, The Crucified Peoples: Yahweh's Suffering Servant Today. The crucified Christ has taken upon himself and got rid of the sin 
of the world (Sobrino 1990:127). Thus, just as Christ is crucified, so are the poor, the oppressed and the marginalised.

Gutierrez argues strongly that the notion of liberation is more exact and all-embracing, far more than the word development and this emphasises that human beings transform themselves by conquering their liberty throughout their existence and history (Gutierrez 1973:xiv). He goes on to argue that the Bible presents liberation-salvation-in Christ as the total gift, which gives the whole process of liberation its deepest meaning and its complete and unforeseeable fulfilment (Gutierrez 1973:xiv). Liberation, which is a salvific process, is multidimensional and involves one's relationship with other human beings and with the Lord and which makes liberation theology a theology that is not unrelated to salvation (cf. Gutierrez 1973:xiv).

\section{Irruption of the poor as a new presence}

The poor used to be ignored as if they are absent in history and historical processes. They are now present according to liberation theologians. According to Gutierrez (1973:xx), there is now a new presence of those who used to be 'absent' from society and from the church (cf. Gutierrez 1999:20). Absent is put in quotation marks, as in reality the poor and oppressed have always been present (Gutierrez 1981:108). The poor and the marginalised cannot be wished away. It is the dominant ones who choose to ignore and suppress them.

By absent, Gutierrez (1973:xx) and other theologians refer to being of no importance and being without an opportunity to give expression themselves to their sufferings, their comraderies, their plans and their hopes. This new presence is referred to as 'the irruption of the poor' (Gutierrez 1973:xx; cf. Gutierrez 1999:20). As a result of this irruption of the poor, their new presence becomes a reality in history and in the historical processes. Gutierrez (1999:20) states that the poor have burst upon the social scene with their 'poverty on their shoulders'. Those who were for a long time 'absent' in our society and in the church have made themselves - and are continuing to make themselves present (Gutierrez 1999:20).

Gutierrez (1973:xx) acknowledges that this changed State of Affairs became a reality not only in Latin America but also in the United States of America, in Africa and Asia. As a result of this changed State of Affairs, liberation theology is bound up with the new presence of those who were always 'absent' from history (Gutierrez 1973:xxi). They are now active agents of their own destiny and in that way launched a resolute process that is changing the condition of the poor and oppressed of this world (Gutierrez 1973:xxi). The poor and oppressed have agency and they assert their new presence in history, in the church and in society. The presence of the poor is making itself felt first in the struggles of the common people for liberation and the new historical awareness associated with those struggles (Gutierrez 1973:108).

\section{The preferential option for the poor}

As a result of liberation theology, a significant number of Christians became conscientised and:

$[M]$ ade an option to go to the poor and engage them in a reinterpretation of their own religious tradition in a way that is more biblically based and gives a transformative rather than a fatalistic stance towards the world. (Berryman 1987:42)

The expression, 'preferential option for the poor' emerged from within the Christian communities, between the time of the conferences of Medellin and Puebla (Gutierrez 1999:27).

This is in line with the position taken by the bishops at Medellin who reaffirmed a clear option for and solidarity with the poor (Berryman 1987:43). The bishops stated: 'We affirm the need for a conversion on the part of the whole Church to a preferential option for the poor, aimed at their integral liberation' (Bishops cited in Berryman 1987:43-44).

The 'preferential option for the poor' became a slogan encapsulating the central thrust of the Puebla meeting and endorsing solidarity with the poor as God's will for the church (Berryman 1987:44). According to Berryman (1987:43), this option for the poor as originally formulated by the bishops at Medellin, was a rediscovery and a contemporary application of a central element of the Scriptures. In line with the preferential option for the poor, the God of life, God of the Old Testament is God of the poor and the oppressed. He is the God who sides with them, taking part in their struggles and identifying with them (Brown 1978:61). The God of the New Testament is the same God, a God who becomes incarnate not in on one who possessed wealth or influence or a good name (Brown 1987:61). Here, God is on the side of the poor and oppressed in their struggle for freedom (Maimela 1990:176). According to 'the preferential option of the poor' God and theologians cannot afford to be neutral when God's people are subjected to suffering. Black theologians argue that there is no such thing as 'theological neutrality' (Chikane 1985:101). Theologians and Christians in general are called to practice a spirituality that is rooted in the option for the oppressed people as theologians and the poor hold hands in the struggle for liberation. As Christians, we are on the side of the poor only when we struggle alongside them and together with them, against poverty that has been unjustly created and forced upon them (Boff \& Boff 1987:4).

Boff and Boff (1987:4) states that service in solidarity with the oppressed also implies an act of love for the suffering Christ, a liturgy pleasing to God. Cone (1997:ix) challenges theologians and preachers of the Christian gospel to make it unquestionably clear that the God of Moses and Jesus makes an unqualified solidarity with the victims, empowering them to fight against injustice.

\section{Conclusion}

The article attempted to trace liberation theology and black theology from the beginning of the use of the expression 
liberation theology. It also argued that liberation theology is not only political and radical, but spirituality and faith are important to the poor and oppressed as they struggle in the context of poverty.

The article argues that black theology is as theological as other theologies. The article concludes that liberation theology as a critical theological reflection in the context of poverty is not unrelated to the faith and spirituality of the poor and oppressed. Faith and spirituality are central to liberation theology, as the poor and oppressed engage in theoretical reflection while undertaking the spiritual journey of faith. The poor and oppressed have in different contexts of poverty and oppression made their presence a reality, in contexts where they were declared 'absent' and they actualise their agency in the struggle for liberation. As they do this, they do so as part of the journey of their spirituality and faith. That journey of faith continues in the South African context as the poor and oppressed reflect theologically amid pain and suffering brought about by poverty and oppression. The spirituality and the liberating Christian praxis and activism must remain inseparable in the journey of the poor and the oppressed.

\section{Acknowledgements Competing interests}

The author declares that he has no financial or personal relationships that may have inappropriately influenced him in writing this article.

\section{Author's contributions}

O.A.B. is the sole author of this article.

\section{Ethical considerations}

This article followed all ethical standards for research without direct contact with human or animal subjects.

\section{Funding information}

This research received no specific grant from any funding agency in the public, commercial or not-for-profit sectors.

\section{Data availability}

Data sharing is not applicable to this article as no new data were created or analysed in this study.

\section{Disclaimer}

The views and opinions expressed in this article are those of the author and do not necessarily reflect the official policy or position of any affiliated agency of the author.

\section{References}

Assmann, H., 1975, Practical theology of liberation, Search Press, London.

Berryman, P., 1987, Liberation theology: The essential facts about the revolutionary movement in Latin America and beyond, Pantheon Books, New York, NY.
Biko, S., 1978, 'The church as seen from a young Layman, in Steve Biko 1947-1977: I write what I like', in A. Stubbs (ed.), Steve Biko 1947-1977: I write what I like, pp. 54-60, Heinemann, Oxford.

Boesak, A., 1976, Farewell to innocence: A socio-ethical study on black theology and power, Orbis Books, Maryknoll, NY.

Boesak, A., 1979, 'Liberation theology in South Africa', in K. Appiah-Kubi \& S. Torres (eds.), African theology en route, pp. 169-175, Orbis Books, Maryknoll, NY.

Boff, L. \& Boff, C., 1979, Salvation and liberation: In search of a balance between faith and politics, Orbis Books, Maryknoll, NY.

Boff, L. \& Boff, C., 1987, Introducing liberation theology, Burns \& Oates, Turnbridge Wells.

Boshoff, C.W.H., 1972, 'Die betekenis van die swart teologie vir kerk en sending in Suid-Afrika: Die swart teologie as bevrydigingsbeweging', in C.W.H. Boshoff, P.E.S. Smith \& D. Crafford (eds.), Swart teologie, pp. 1-22, N. G. Kerkboekhandel, Pretoria.

Brown, R.M., 1978, Theology in a new key: Responding to liberation themes, The Westminister Press, Philadelphia.

Buthelezi, M., 1972, An African theology or a black theology, in essays on black theology, pp. 3-9, University Christian Movement, Johannesburg.

Chikane, F., 1985, 'Doing theology in a situation of conflict', in C. Villa-Vicencio \& J.W. De Gruchy (eds.), Resistance and hope: South African essays in honour of Beyers Naude, pp. 98-102, David Phillip, Cape Town.

Cone, J., 1972, 'Black theology and Black liberation', in M. Motlhabi (ed.), Essays on black theology, pp. 28-36, University Christian Movement, Johannesburg.

Cone, J., 1997, Black theology and black power, Orbis Books, Maryknoll, NY.

Crafford, 1972, 'Swart Teologie en die Ned. Geref. Kerk in Afrika', in C.W.H. Boshoff, P.E.S. Smith \& D. Crafford (eds.), Swart Teologie, pp. 45-59, N. G. Kerkboekhandel, Pretoria.

Gibellini, G., 1987, The liberation theology debate, SCM Press, London.

Goba, B., 1988, An agenda for black theology: Hermeneutics for social change, Skotaville, Braamfontein.

Gutierrez, G., 1973, A theology of liberation, transl. S.C. Inda \& J. Eagleson, Orbis Books, Maryknoll, NY.

Gutierrez, G., 1981, 'The irruption of the poor in Latin America and the Christian communities of the common people', S. Torres \& J. Eagleson (eds.), The challenge of basic Christian communities, pp. 107-123, Orbis Books, Maryknoll, NY.

Gutierrez, G., 1983, The power of the poor in history, SCM Press, London.

Gutierrez, G., 1999, The task and content of liberation theology, transl. J. Condor, pp. 19-38, Oxford University Press, Oxford.

Hopkins, D. (ed.), 2002, 'Spirituality and transformation', in Heart and head, pp. 77-90, Palgrave McMillan, New York, NY.

Maimela, S.S., 1990, Modern trends in theology, Skotaville, Braamfontein.

Mbiti, J., 1969, African religions and philosophy, Heinemann, London.

Metz, J.B., 1990, 'With the eyes of a European theologian', in L. Boff \& B. Elizondo (eds.), 1492-1992 the voice of the victims, pp. 113-119, SCM Press, London.

Motlhabi, M., 1972, 'Foreword', in Essays on black theology, pp. 1-2, University Christian Movement, Johannesburg.

Ngcukaitobi, T., 2018, The land is ours: South Africa's first black lawyers and the birth of constitutionalism, City Penguin Books, Century.

Pinn, A.B., 2010, 'Black theology', in S. Floyd-Thomas \& A.B. Pinn (eds.), Liberation theologies in the United States: An introduction, pp. 15-36, New York University Press, New York, NY.

Pityana, N., 1972, 'What is black consciousness', in Essays in black theology, pp. 37-43, University Christian Movement, Johannesburg.

Reddie, A.G., 2020, 'Crisis in Black Theology: Reasserting a future based on spiritual liberative praxis', HTS Teologiese Studies/Theological Studies 76(3), a6152. https://doi.org/10.4102/hts.v76i3.6152

Smith, P.E.S., 1972, 'Swart teologie en die sending van die kerk in Afrika', in C.W.H. Boshoff, P.E.S. Smith \& D. Crafford (eds.), Swart teologie, pp. 23-44, N. G. Kerkboekhandel, Pretoria.

Sobrino, J., 1990, 'The crucified peoples: Yahweh's suffering servants today', in L. Boff \& B. Elizondo (eds.), 1492-1992 the voice of the victims, pp. 120-129, SCM Press, London.

Sobrino, J., 1996, 'Spirituality and the following of Jesus', in J. Sobrino \& I. Ellacuria (eds.), Systematic theology: Perspectives from liberation theology, pp. 233-256, Orbis Books, Maryknoll, NY.

Tutu, D., 1979, 'The theology of liberation in Africa', in K. Appiah-Kubi \& S. Torres (eds.), African theology en route, pp. 162-168, Orbis Books, Maryknoll, NY.

Tutu, D., 1985, 'Spirituality: Christian and African', in C. Villa-Vicencio \& J.W. De Gruchy (eds.), Resistance and hope: South African essays in honour of Beyers Naudé, pp. 159-164, David Phillip, Cape Town.

Vellem, V., 2012, 'Interlocution and black theology of liberation in the 21st century: A reflection', Studia Historiae Ecclesiasticae 38(Suppl 1), 1-9.

Vellem, V., 2013, 'The "native experiment": The formation of the Bantu Presbyterian Church and the defects of faith transplanted on African soil', Missionalia 41(2), 146-162.

Vellem, V. S., 2014, 'Spirituality of liberation: A conversation with African religiosity', HTS Teologiese Studies/Theological Studies 70(1), Art. \#2752, 7 pages. https://doi. org/10.4102/hts.v70i1.2752

Vila-Vicencio, C., 1988, Trapped in Apartheid: A socio-theological history of the English-speaking churches, Orbis Books, Maryknoll, NY. 